\author{
Journal of Sustainability Business Research (JSBR) \\ Vol-1,Issue-1,Desember (JSBR) \\ E-ISSN: 2746-8607 \\ http://jurnal.unipasby.ac.id/index.php/jsbr
}

\title{
Analisis Penerapan Sistem Informasi Penggajian dan Pengupahan Dalam Peningkatan Kinerja Karyawan Pada Pt. Enwe Putra Perkasa
}

Andika Windiarti1 ${ }^{1}$, Moh.Afrizal M, 2

Universitas PGRI Adi Buana Surabaya ${ }^{1,2}$

andikawindiarti45@gmail.com

The application of payroll and wage accounting systems at PT. Enwe Putra Perkasa is a system carried out by the company to find out whether the payroll system is running well or not, by looking at related functions, related documents, related records and procedures for making payroll. The results showed a related function in the payroll accounting system in PT. Enwe Putra Perkasa is not fully in accordance with the related functions that have been explained in theory. Related documents in the payroll accounting system in PT. Enwe Putra Perkasa is good enough and almost in accordance with related documents that have been explained in theory. Notes relating to the accounting system of the payroll accounting system at PT. Enwe Putra Perkasa is not fully in accordance with the records used in the sales accounting system that have been explained in theory.

\section{Keywords: accounting information system, Payroll and Wages}

\section{Latar Belakang}

System gaji yang dilakukan PT. Enwe Putra Perkasa semua sama antara karyawan kantor dengan karyawan bagian lapangan, yang dilakukan sebulan sekali, namun ada perhitungan lagi untuk insentif, uang makan, lembur dan bonus lainnya.

Dalam praktiknya terjadi beberapa masalah didalam perusahaan terkait dengan penggajian karyawan PT. Enwe Putra Perkasa, yaitu terjadinya ketidakcocokan absensi, terjadi salah hitung dalam jumlah pembayaran gaji dan lembur, tidak adanya otorisasi dan fungsi terkait yang menjalankan sesuai fungsinya pada system akuntansi penggajian, dan terjadi perangkapan tugas pada system akuntansi penggajian dan pengupahan yang berjalan di PT.Enwe Putra Perkasa seperti fungsi keuangan. Adanya permasalahan yang timbul pada system akuntansi penggajian dan pengupahan pada PT.Enwe putra perkasa menyebabkan karyawan protes karena ada perhitungan gaji yang tidak sesuai dengan gaji yang seharusnya mereka tertima karena masing-masing karyawan sudah bisa menghitung dan memperkirakan berapa besar gaji yang bakal mereka terima. Kejadian ini dikhawatirkan akan berdampak negative terhadap peningkatan kinerja karyawan. Oleh sebab itu untuk meningkatkan kinerja pada perusahaan PT.Enwe putra perkasa harusnya perusahaan memperhatikan hal-hal yang berkaitan dengan gaji. Karena gaji merupakan hal yang sangat sensitive bagi karyawan.

Berdasarkan uraian diatas, penulis tertarik untuk melakukan penelitian dengan judul "Analisis Penerapan Sistem Informasi Penggajian dan Pengupahan Dalam Peningkatan Kinerja Karyawan Pada Pt. Enwe Putra Perkasa". 
Journal of Sustainability Business Research (JSBR)

Vol-1,Issue-1,Desember (JSBR)

E-ISSN: 2746-8607

http://jurnal.unipasby.ac.id/index.php/jsbr

Sistem Akuntansi Penggajian dan Pengupahan

Mulyadi (2016:182) fungsi yang terkait dalam sistem akuntansi penggajian adalah :

1. Fuungsi Kepuegawaian

2. Fungsii pencataatan waaktu

3. Fuungsi pembuuatan daaftar gaji

4. Fungsi akuntansi

5. Fungsi keuangan

Mulyadi (2016 : 185) dokumen yang di gunakan dalam sistem akuntansi penggajian ada 7 macam, yaitu:

1. Dokmumen pendukuung perubahaan gaji

2. Kartu jaam hadir

3. Kaartu jam kerja

4. Daftar gaji dan daftar upah

5. Rekaap daftar gaji dan rekap daftar upah

6. Slip Gajii

7. Buukti kkas keluar

\section{Subyek dan Obyek Penelitian}

Kepala HRD PT.Enwe Putra Perkasa menjadi subyek dalam penelitian ini. Peneliti akan mengambil data dengan menggunakan wawancara dengan Kepala HRD. Peneliti akan membuat janji dengan Kepala HRD untuk melakukan wawancara.

Adapun obyek penelitian adalah siistem akuntanssi penggaajian diPT.Enwe Putra Perkasa tahun 2019.

\section{Analisis data dan hasil penelitian}

Fungsi Terkait penggajian pada PT.Enwe Putra Perkasa

1. Fungsi personalia.

Personalia bertanggunga jawab untuk mengabsen karyawan. Absen karyawan dilakukan dengan menggunakan finger print. Setiap karyawan yang dating diwajibkan absen. Jika tidak, maka karyawan tersebut dianggap tidak masuk kerja.

2. Fungsi akuntansi.

Pada PT.Enwe putra perkasa fungsi akuntansi mempunyai tugas membuat daftar gaji karyawan. Setelah daftar gaji selesai dibuat.selanjutnya diberikan ke bagian keuangan. Pada bagian ini juga harus memastikan perhitungan gaji karyawan harus sesuai dengan hari kerja karyawan.

3. Fungsi Keuangan.

Fungsi ini bertugas membagikan gaji karyawan.biasanya gaji akan diberikan ke karyawan setelah karyawan selesai kerja dan diberikan secara langsung. Dan uang dimasukkan didalam amplop.

\section{Dokumen Terkait penggajian pada PT.Enwe Putra Perkasa}


Journal of Sustainability Business Research (JSBR)

Vol-1,Issue-1,Desember (JSBR)

E-ISSN: 2746-8607

http://jurnal.unipasby.ac.id/index.php/jsbr

1. Daftar Hadir

Dokumen daftar hadir Pada PT.Enwe Putra Perkasa berupa hasil print out dari finger print yang telah dicetak oleh bagian HRD. Masing-masing karyawan harus melakukan absensi sendiri-sendiri. Tidak diperbolehkan menitipkan absen ke temannya.

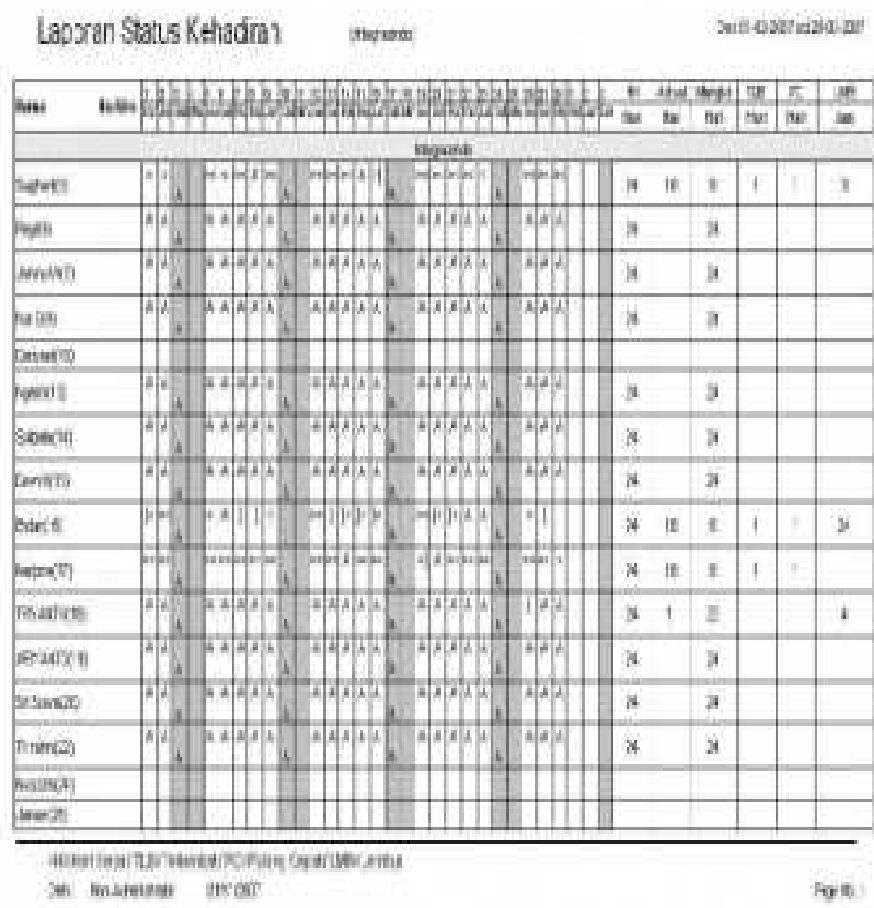

Gambar 1

Laporan Status Kehadiran

2. Dokumen Pembayaran Gaji

Dokumen pembayaran gaji Pada PT.Enwe Putra Perkasa dibuat oleh bagian keuangan. Dokumen ini dibuat oleh bagian keuangan setelah mendapatkan laporan dari personalia berupa hasil absensi karyawan. Selanjutnya bagian keuangan membuat dokumen ini. Dokumen pembayaran gaji dipakai sebagai acuan dalam memberikan gaji ke karyawan.

3. Rekapitualsi Daftar Gaji

Dokumen Rekapitualsi Daftar Gaji Pada PT.Enwe Putra Perkasa digunakan sebagai dasar pemberian gaji karyawan yang distorkan ke direktur untuk dimintaakan ACC. Dokumen ini harus di setujui / di ACC oleh direktur. Karena tanpa adanya persetujuan direktur gaji tidak bisa dicairkan atau diberikan .

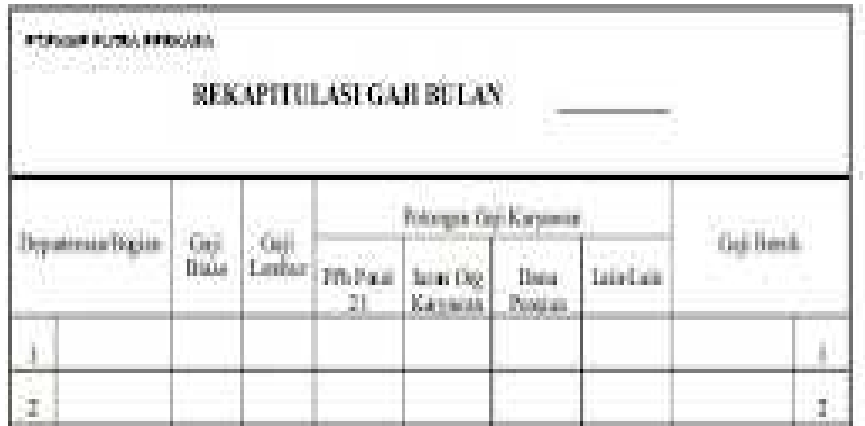


Journal of Sustainability Business Research (JSBR)

Vol-1,Issue-1,Desember (JSBR)

E-ISSN: 2746-8607

http://jurnal.unipasby.ac.id/index.php/jsbr

Gambar 2

Rekapitulasi gaji bulanan

4. Slip Gaji

Slip gaji pada PT.Enwe Putra Perkasa merupakan bukti dan perhitungan uang gaji yang diterima olehh karyawan. Pada slip gaji tertera berapa hari mereka bekerja dan jumlah gaji yang diterima. Dari slip gaji ini karayawan akan mengetahui perhitungan dari gaji yang mereka terima. Di slip gaji juga terdapat perhitungan pemotongan gaji bagi karyawan yang dalam satu bulan tidak masuk kerja. Sehingga karyawan tau berapa besar gaji yang dipotong karena tidak masuk kerja. Apabila ada ketidak sesuaian nominal gaji yang diterima atau ada keterangan yang kurang sesuai, maka karyawan bila melakukan protes atau keluhan ke bagian personalia.

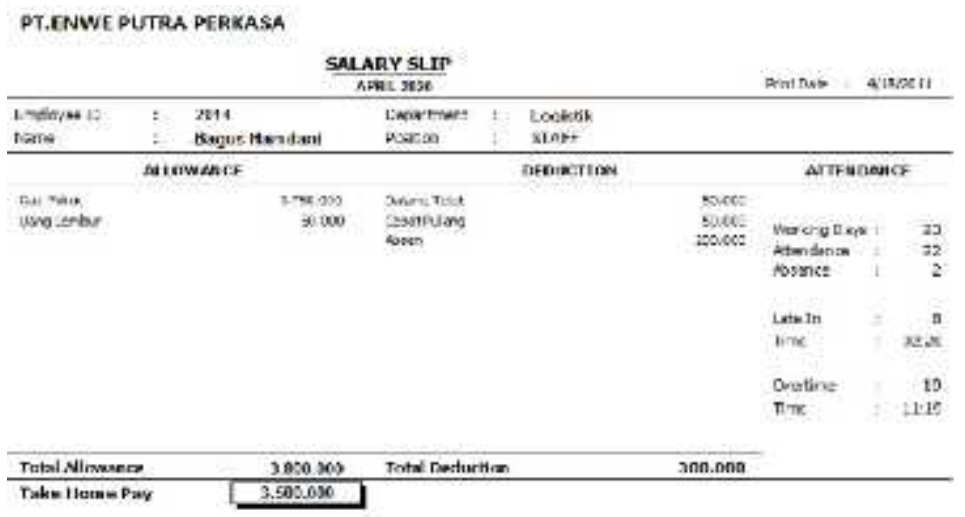

Gambar 3

Dokumen Slip Gaji

5. Bukti kas keluar 
Journal of Sustainability Business Research (JSBR)

Vol-1,Issue-1,Desember (JSBR)

E-ISSN: 2746-8607

http://jurnal.unipasby.ac.id/index.php/jsbr

Dokumen ini dipakai untuk bukti bahwa sejumlah uang sudah dikeluarkan oleh bagian keuangan dari kas. Bukti kas keluar harus melewati persetujuan dari direktur. Bukti kas ini akan diarsipkan oleh bagian keuangan agar pada kemudian hari kalau ada audit atau pemeriksaaan bisa dijadikan dokumen.

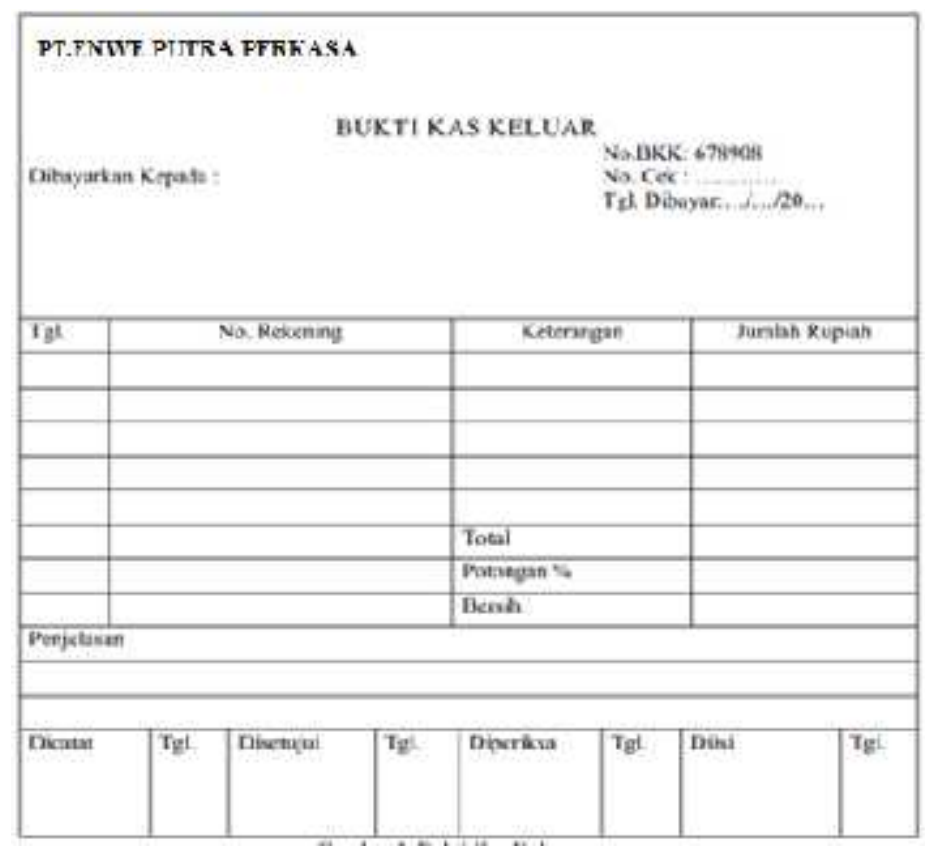

Gambar 4

Dokumen Bukti Kas Keluar

\section{Catatan Terkait sistem akuntansi penggajian PT. Enwe Putra Perkasa}

1. Buku jurnal

Buku jurnal umum pada PT.Enwe Putra Perkasa digunakan untuk mencatat biaya-biaya tenaga kerja dan biaya lainnya yang timbul dalam aktivitas perusahaan kedalam setiap departemen didalam perusahaan.

2. Kartu Penghasilan Karyawan

Kartu Penghasilan Karyawan pada PT.Enwe putra perkasa dipakai untuuk mencatat penghasilan karyawan.

\section{Jaringan Prosedur yang membentuk Sistem Penggajian PT. Enwe Putra Perkasa}

1. Prosedur Pencatatan waktu hadir

Pada waktu karyawan PT.Enwe putra perkasa akan mulai bekerja, mereka diwajibkan melakukan absensi sesuai ditempat / kantor mereka masing-masing dengan menempelkan jari pada mesin Finger print. maka secara otomatis alat tersebut mencatat waktu hadir setiap karyawan. Karyawan yang berkantor dikantor pusat bias melakukan absensi dikantor pemasaran jika karyawan tersebut ada tugas atau pekerjaan yang harus dikerjakan dikantor 
Journal of Sustainability Business Research (JSBR)

Vol-1,Issue-1,Desember (JSBR)

E-ISSN: 2746-8607

http://jurnal.unipasby.ac.id/index.php/jsbr

pemasaran atau diproject. Namun karytawan tersebut harus melakukan pemberitahuan kepada bagian HRD.

\section{Prosedur Pembuatan Daftar Gaji}

Prosedur ini pada PT.Enwe putra perkasa dilaksanakan oleh bagian keuangan berdasarkan data absensi karyawan pada output finger print yang diserahkan dari bagian personalia. Daftar gaji karyawan dibuat rangkap dua, 1 rangkap untuk dijadikan arisp dan satu rangkap diserahkan kepada direktur untuk arsip direktur

3.Prosedur pembayaran gaji

Prosedur ini dilakukan secara tunai dengan memasukkan gaji karyawan pada amplop dan dibagikan oleh bagian keuangan setelah pulang kerja pada akhir bulan setiap bulannya. Jika akhir bulan jatuh pada tanggal merah, maka gaji akan duiberikan pada hari besoknya. Hal ini sudah menjadi kesepakatan dengan karyawan. Dan semua karyawan sudah dikasih pemberitahuan. Sehingga semua karyawan paham dan tidak akan melakukan protes.

\section{Pembahasan}

1. Fungsi yang terkait PT. Enwe Putra Perkasa

fungsi-fungsi yang berkaitan dengan penggajian PADA pt.Enwe putra perkasa cukup baik, seperti bagian personalia yang berjalan sesuai fungsinya, dan bagain keuangan dan akauntansi juga sudah berjalan sesuai dengan fungsinya masing-masing.

2. Dokumen Terkait sistem akuntansi penggajian pada PT. Enwe Putra Perkasa.

Dokumen yang digunakan dalam sistem akuntansi penggajian pada PT. Enwe Putra Perkasa yaitu Dokumen Daftar Hadir, Dokumen Pembayaran Gaji, Rekapitualsi Daftar Gaji, Slip Gaji dan Bukti kas keluar. Dokumen terkait di sistem akuntansi penggajian yang ada di PT. Enwe Putra Perkasa sedikit berbeda dengan yang ada di teori.

Dari penjelasan diatas, maka dokumen terkait dalam sistem akuntansi penggajian yang ada di PT. Enwe Putra Perkasa sudah cukup baik dan hampir sesuai dengan dokumen terkait yang telah dijelaskan pada teori.

3. Catatan Terkait sistem akuntansi penggajian pada PT. Enwe Putra Perkasa.

Catatan yang dipakai oleh perusahaan sudah baik dan bisa dipakai, namun perlu ada perbaikan. Sehingga system akan bekerja dan berjlan lebih baik.

\section{Simpulan}

1. Berdasarkan hasil analisis data dengan mengacu pada tujuan penelitian dan model analisisa, maka kesimpulan pada penelitian ini adalah fuungsi yaang terkaiit dalam sistem akuntasni di PT. Enwe Putra Perkasa belum sepenuhnya sesuai dengan fungsi terkait yang telah dijelaskan pada teori. Karena masih ada fungsi yang rangkap pada PT. Enwe Putra Perkasa yaitu fungsi personalia. Dokumen terkait dalam sistem 
Journal of Sustainability Business Research (JSBR)

Vol-1,Issue-1,Desember (JSBR)

E-ISSN: 2746-8607

http://jurnal.unipasby.ac.id/index.php/jsbr

akuntansi penggajian yang ada di PT. Enwe Putra Perkasa sudah cukup baik dan hampir sesuai dengan dokumen terkait yang telah dijelaskan pada teori. Namun ada dokumen yang dijelaskan pada teori menurut mulyadi, namun tidak ada pada PT.Enwe putra perkasa, Kartu jam hadir dan Kartu jam kerja. Serta Catatan terkait sistem akuntansi sistem akuntansi penggajian pada PT. Enwe Putra Perkasa.

\section{Implikasi}

Pada Hasil penelitian ini diperoleh mempunyai implikasi system akuntansi penggajian pada PT.Enwe putra perkasa bahwa system penggajian yang berjalan sudah cukup baik, namun harus ada perbaikan sehinggan system pegajian pada PT.Enwe putra perkasa semakin baik dan berjalan dengan lancar.

\section{Keterbatasan Penelitian}

Penelitian ini mempunyai keterbatasan bahwa pemberi informasi dalam posiis bekerja ketika dimuntai informasi sehingga diakutkan hasil diragukan subjektifitasnya oleh peneliti.

\section{Daftar Rujukan}

Arfan Ikhsan dan Ida Bagus Teddy Prianthara. 2014. Sistem Akuntansi Perhotelan. Yogyakarta : Graha IImu

Mulyadi. 2016. Sistem Akuntansi,Edisi 3,Jakarta:SalembaEmpat

Nugroho, Widjajanto. 2015. Siistem Informasi Akuntanssi, Erlangga, Jakarta

Suwatno, dan Tjutju Yuniarsih. 2015. Manajemen Sumber Daya Manusia. Bandung: Alfabeta. 
Journal of Sustainability Business Research (JSBR)

Vol-1,Issue-1,Desember (JSBR)

E-ISSN: 2746-8607

http://jurnal.unipasby.ac.id/index.php/jsbr 
Journal of Sustainability Business Research (JSBR)

Vol-1,Issue-1,Desember (JSBR)

E-ISSN: 2746-8607

http://jurnal.unipasby.ac.id/index.php/jsbr 
